\title{
Zanthoxyli Fructus induces growth arrest and apoptosis of LNCaP human prostate cancer cells in vitro and in vivo in association with blockade of the AKT and AR signal pathways
}

\author{
YANG YANG $^{1}$, TAKAYUKI IKEZOE ${ }^{1}$, TAMOTSU TAKEUCHI ${ }^{2}$, YOSHIHIRO ADACHI ${ }^{2}$, \\ YUJI OHTSUKI $^{2}$, H. PHILLIP KOEFFLER ${ }^{3}$ and HIROKUNI TAGUCHI ${ }^{1}$ \\ Departments of ${ }^{1}$ Hematology and Respiratory Medicine, ${ }^{2}$ Tumor Pathology, Kochi Medical School, \\ Kochi University, Okohcho, Nankoku, Kochi 783-8505, Japan; ${ }^{3}$ Cedars-Sinai Medical Center, \\ UCLA School of Medicine, Los Angeles, CA 90048, USA
}

Received October 11, 2005; Accepted December 8, 2005

\begin{abstract}
Zanthoxyli Fructus belongs to the family of oranges and is used as a seasoning in Asian countries including Japan. This study found that a water extract of Zanthoxyli Fructus possessed anti-tumor activity against a wide variety of cancer cells including those from prostate (LNCaP, DU145, PC-3), breast (MCF-7, T47D, MDA-MB231), lung (NCI-H460, $\mathrm{H} 520$ ), as well as leukemia (HL-60, NB4, Jurkat) in vitro, as measured by the trypan blue exclusion test. Importantly, Zanthoxyli Fructus slowed the proliferation of LNCaP, DU145, and MDA-MB231 cells present as xenografts in BALB/c nude mice without adverse effects. Further studies explored the molecular mechanism by which Zanthoxyli Fructus inhibited the proliferation of androgen-dependent human prostate cancer LNCaP cells because Zanthoxyli Fructus possessed the strongest anti-tumor activity against these cells. Zanthoxyli Fructus blocked androgen receptor (AR) signaling in conjunction with down-regulation of nuclear levels of AR and induced apoptosis of these cells, as measured by the reporter assay, Western blot analysis, and TUNEL assay, respectively. As expected, Zanthoxyli Fructus also decreased the level of the AR-target molecule, prostate-specific antigen in these
\end{abstract}

Correspondence to: Dr Takayuki Ikezoe, Department of Hematology and Respiratory Medicine, KMS, Kochi University, Nankoku, Kochi 783-8505, Japan

E-mail: ikezoet@med.kochi-ms.ac.jp

Abbreviations: PSA, prostate specific antigen; AR, androgen receptor; AREs, androgen response elements; DHT, $5 \alpha$-dihydrotestosterone; FBS, fetal bovine serum; STAT3, signal transducers and activators of transcription 3; nuclear factor-кB, NF-кB; PI3-K, phosphatidylinositol 3-kinase; GSK-3, glycogen synthase kinase-3; siRNA, small interfering RNA

Key words: Zanthoxyli Fructus, androgen receptor, prostate specific antigen, AKT, cyclin D1 cells. Furthermore, Zanthoxyli Fructus inhibited AKT kinase and down-regulated levels of cyclin D1 protein, as measured by the AKT kinase assay with GSK- $3 \alpha / \beta$ as a substrate and Western blot analysis, respectively. Taken together, Zanthoxyli Fructus might be useful as an adjunctive therapeutic agent for the treatment of individuals with a variety of cancer types.

\section{Introduction}

Zanthoxyli Fructus belongs to the family of oranges and has been used as a seasoning in Asian countries including Japan. Also, Zanthoxyli Fructus is one of the components of a three herbal mixture called Dai-kenchu-to, which stimulates intestinal motility and has been used for treatment of postoperative ileus in Japan. Zanthoxyli Fructus has been shown to increase contraction of the jejunum (1).

Androgens play an important role in the development and maintenance of the normal prostate as well as the initiation and progression of prostate cancer $(2,3)$. Androgen deprivation therapy remains the mainstay of treatment for prostate cancer, once it has progressed outside the prostatic capsule (3). The androgen receptor (AR) belongs to the steroid hormone subfamily of nuclear hormone receptors. It is complexed in the cytoplasm to chaperone proteins that keep the receptor in a transcriptionally inactive form. Upon binding to androgens, AR dissociates from the chaperone and translocates to the nucleus where it binds to androgen response elements (AREs), recruits coregulators, and activates target genes such as prostate-specific antigen (PSA) (2,3). Recently, microarray analysis identified AR as the only up-regulated gene in androgen-independent prostate cancer cells compared to androgen-dependent prostate cancer cells (4). These data suggested that AR might be a promising molecular target for treatment of prostate cancer.

PSA belongs to the kallikrein-like serine protease family; it is produced almost exclusively by the prostate epithelial cells, and is used as a serum marker to help in the diagnosis and to monitor the progression of prostate cancer (5). The 5' upstream promoter and enhancer region of the PSA gene contains up to six AREs to which ligand activated AR binds and induces expression of PSA (5-8). 
AKT is a serine (Ser)/threonine (Thr) protein kinase and plays an important role in controlling cell growth and apoptosis (9). Phosphatidylinositol 3-kinase (PI3-K) is upstream of the AKT, activating AKT by phosphorylation of the protein at Ser473 and Thr308 (9). The activated AKT phosphorylates target molecules including Bad, forkhead transcriptional factor (FKHR), and glycogen synthase kinase-3ß (GSK-3ß), which cumulatively have anti-apoptotic effects (10-12). PTEN phosphatase is a major negative regulator of the PI3-K/AKT signal pathway $(13,14)$. In many cancer types including those from prostate, PTEN is inactivated by several mechanisms such as either homozygous deletions, hemizygous deletion and mutation on the second allele, or methylation of its promoter region. Loss of expression of this phosphatase results in constitutive activation of AKT signaling $(15,16)$.

The D-type cyclins, D1, D2 and D3, are closely related proteins whose expression is induced by mitogens and growth factors (17) and down-regulated by growth factor deprivation or by antimitogens (18). The D-type cyclins associate with cyclin-dependent protein kinase Cdk4 or Cdk6 to form an active complex that phosphorylates and inactivates the retinoblastoma protein, $\mathrm{pRb}$, resulting in prolonged cell survival (19). Cyclin D1 is aberrantly overexpressed in many types of cancer including those from breast, colon and prostate (20-23). Previous studies showed that the level of cyclin D1 is regulated by GSK-3ß, which phosphorylates cyclin D1 on Thr286, leading to degradation via ubiqutin-dependent $26 \mathrm{~S}$ proteasome (24). Thus, activated AKT inhibits GSK-3ß kinase and increases the level of cyclin D1 protein. This study found that Zanthoxyli Fructus inhibited growth of a wide variety of cancer cells in vitro and in vivo. It showed the strongest anti-tumor activity against androgen-dependent prostate cancer LNCaP cells. Zanthoxyli Fructus downregulated levels of PSA and cyclin D1 in conjunction with blockade of signaling by AR and AKT.

\section{Materials and methods}

Cell line. Prostate (LNCaP, PC-3, DU145), breast (MCF-7, T47D, MDA-MB231), lung (NCI-H460 -520), myeloid leukemia (HL-60), and lymphoblastic T-cell leukemia (Jurkat) cells were obtained from American Type Culture Collection (Manassas, VA). NB4 cell line was a kind gift from M. Lanotte (St. Louis Hospital, Paris, France). The cells were maintained in RPMI-1640 with 10\% fetal bovine serum (FBS).

Chemicals. Zanthoxyli Fructus (lot no. 251094010) was obtained from Tsumura (Tokyo, Japan). The purity of Zanthoxyli Fructus was confirmed by three-demensional (3D) chromatography, as previously described (25) (figure not shown). To prepare the extract, $100 \mathrm{mg}$ of Zanthoxyli Fructus was added to $1 \mathrm{ml}$ double distilled water and incubated at $40^{\circ} \mathrm{C}$ for $1 \mathrm{~h}$ in a water bath with constant stirring. The mixture was further sonicated for $5 \mathrm{~min}$, and undissolved solid residue was filtered through a $0.2-\mu \mathrm{m}$ Millipore filter (Millipore Corporation, Bedford, MA). The filtrate was stored at $4^{\circ} \mathrm{C}$.

Trypan blue exclusion test. Leukemia cells $\left(10^{5} / \mathrm{ml}\right)$ and adherent cells $\left(10^{4} / \mathrm{ml}\right)$ were incubated with a variety of concentrations of Zanthoxyli Fructus for 2 days in 96-well plates (Flow Laboratories, Irvine, CA). After culture, cell number and viability were evaluated by staining with trypan blue and counting by light microscopy.

Colony-forming assay. Resuspended mononuclear bone marrow cells from healthy volunteers $\left(5 \times 10^{5}\right.$ cells $\left./ \mathrm{ml}\right)$ were added 1:10 to methylcellulose medium H4534 (StemCell Technologies Inc., Vancouver, British Columbia, Canada) to yield a final concentration of $1 \%$ methylcellulose, $30 \%$ FCS, $1 \%$ BSA, $10^{-4} \mathrm{M}$ mercaptoethanol, $2 \times 10^{-3} \mathrm{M}$ L-glutamine, $50 \mathrm{ng} / \mathrm{ml} \mathrm{stem} \mathrm{cell} \mathrm{factor,} 10 \mathrm{ng} / \mathrm{ml}$ GM-CSF, and $10 \mathrm{ng} / \mathrm{ml}$ IL-3. Cells were plated in six-well plates in a volume of $1 \mathrm{ml}$. Before this step, control diluent or Zanthoxyli Fructus (2 or $4 \mu 1 / \mathrm{ml}$ ) was pipetted into the wells. Cells were incubated at $37^{\circ} \mathrm{C}$ in a humidified atmosphere containing $5 \% \mathrm{CO}_{2}$, and 10 days later, colonies were counted. All experiments were done twice using duplicate plates per experimental point.

Assessment of apoptosis. Apoptotic cell death was examined by terminal deoxyribonucleotide transferase-mediated dUTP nick end-labeling (TUNEL) method using the in situ cell death detection kit (Roche Molecular Biochemicals, Germany) according to the manufacturer's instructions. For quantification, three different fields were counted under the microscope and at least 300 cells were enumerated in each field. All experiments were performed twice.

Plasmids. A 564-bp fragment of the PSA promoter with a 2.4-kb enhancer sequence (-5322 to -2925) cloned upstream of luciferase (PSA P/E-Luc) was used (26). Also, ARE4-E4 Lux, which is the multimerized four consensus AREs from the PSA promoter cloned upstream of the luciferase gene in the pGL3 vector (Promega, Chicago, IL) was utilized (26).

Transfections and luciferase assay. $\mathrm{LNCaP}$ cells were plated in $24-w e l l$ plates and incubated until $60-80 \%$ confluency. Cells were transfected with the indicated plasmids using the GenePorter transfection reagent (Gene Therapy Systems, Inc., San Diego, CA). Following transfection, cells were incubated with $10 \%$ charcoal-stripped FBS RPMI-1640 either with or without DHT $\left(10^{-8} \mathrm{M}\right)$ and either with Zanthoxyli Fructus or control diluent for $24 \mathrm{~h}$. Luciferase activity in cell lysates was measured by the Dual Luciferase assay system (Promega, Madison, WI); and this was normalized by Renilla activities. The results are presented as fold induction, which is the relative luciferase activity of the treated cells over that of control cells. All transfection experiments were carried out in triplicate wells and repeated separately at least 3 times.

Western blot analysis. LNCaP cells were plated on $60-\mathrm{mm}$ plates and incubated until $60-80 \%$ confluency, then the media was replaced with RPMI-1640 containing 10\% charcoal striped FBS either with or without DHT $\left(10^{-8} \mathrm{M}\right)$ and with either Zanthoxyli Fructus or control diluent. After incubation, cells were washed twice in PBS; whole cell lysates and nuclear extracts were prepared as previously described (26). Proteins were resolved by $4-15 \%$ SDS polyacrylamide gel, transferred to an immobilon polyvinylidene difluoride membrane (Amersham Corp., Arlington Heights, IL), and probed 
Prostate

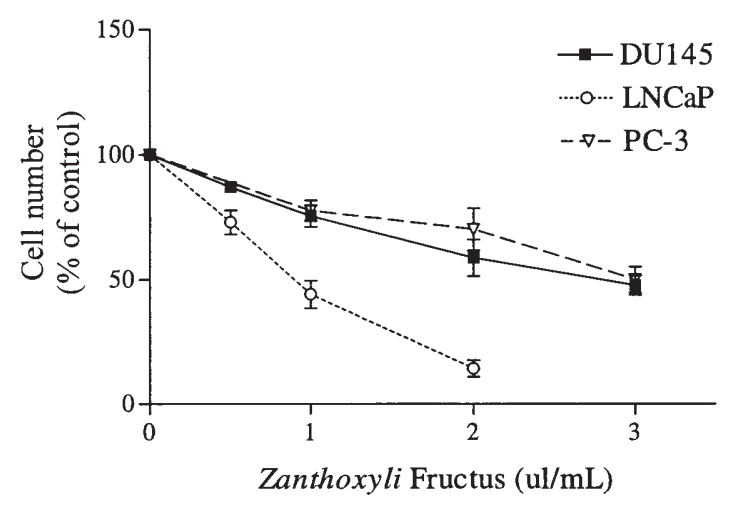

Lung

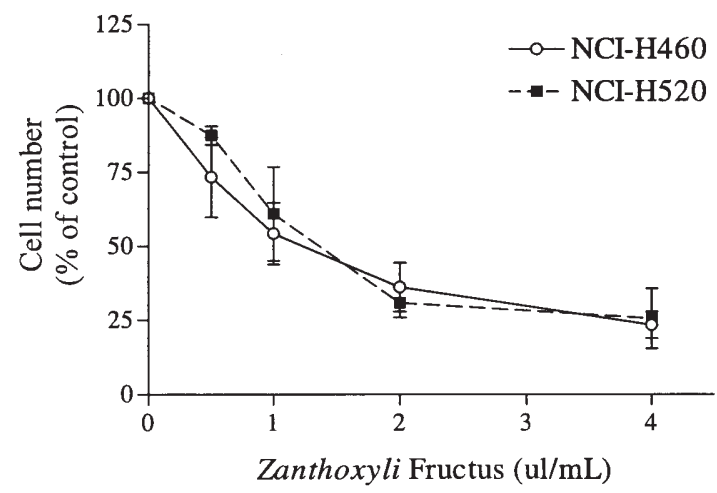

Breast

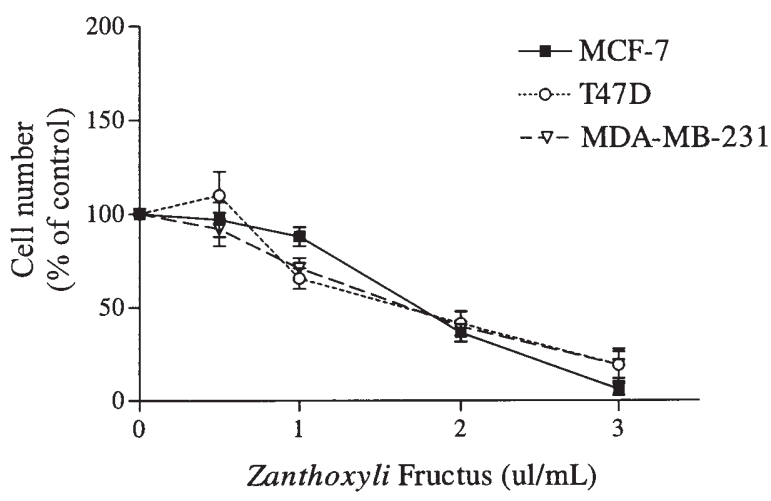

Leukemia

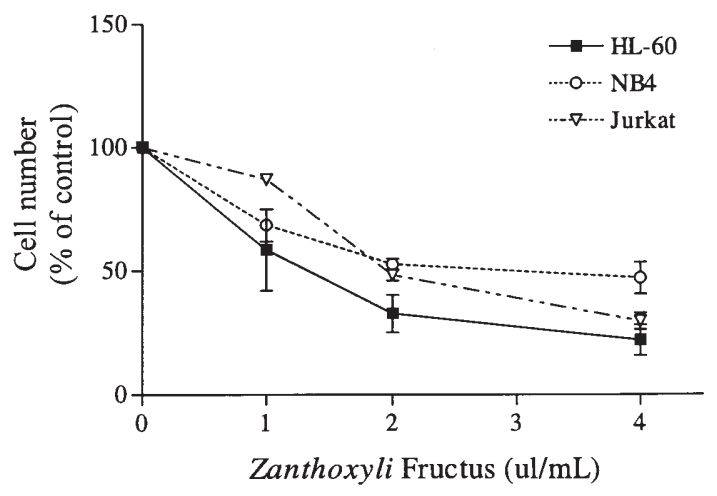

Figure 1. Zanthoxyli Fructus inhibits proliferation of a wide variety of cancer cells. (A) Prostate cancer (LNCaP, DU145, PC-3); (B) breast cancer (MCF-7, T47D, MDA-MB231); (C) non-small cell lung cancer (NCI-H460, NCI-H520); and (D) leukemia (HL-60, NB4, Jurkat) cells were plated in 96-well plates and cultured either with or without Zanthoxyli Fructus $(0.5-4.0 \mu 1 / \mathrm{ml})$. After 2 days, cell number was counted by trypan blue exclusion test. Results represent the mean $\pm \mathrm{SD}$ of three experiment done in triplicate.

sequentially with antibodies. Anti-AR N-20 (Santa Cruz Biotechnology, Inc., Santa Cruz, CA), anti-PSA C-19 (Santa Cruz), anti-cyclin D1 (Santa Cruz), anti-AKT (Cell Signaling, Beverly, MA), anti-p-AKT (Ser ${ }^{473}$ ) (Cell Signaling), anti-pGSK $\alpha / \beta\left(\operatorname{Ser}^{21 / 9}\right)$ (Cell Signaling), and anti-ß-actin (Santa Cruz) antibodies were used. The blots were developed using the enhanced chemiluminescence kit (Amersham Corp.).

AKT immunoprecipitation kinase assay. LNCaP cells were treated with either Zanthoxyli Fructus $(0.5 \mu \mathrm{l} / \mathrm{ml})$ or control diluent. After $24 \mathrm{~h}$, cells were harvested and lysates were prepared. AKT kinase assay was performed using the AKT kinase assay kit (Cell Signaling), according to the manufacturer's instructions. Briefly, $500 \mu \mathrm{g}$ of cell lysates were incubated for $12 \mathrm{~h}$ with protein $\mathrm{G}$-agarose beads bearing antiAKT on a rotator at $4^{\circ} \mathrm{C}$ to immunoprecipitate Akt. This precipitate was next used to phosphorylate a specific substrate, the recombinant GSK-3 $\alpha / \beta$ protein expressed in Escherichia coli. Briefly, $1 \mu \mathrm{g}$ of recombinant GSK-3 $\alpha / \beta$ were incubated with Akt-antibody-protein G-agarose complexes in the presence of magnesium/ATP mixture for $30 \mathrm{~min}$ at $37^{\circ} \mathrm{C}$. Samples were boiled for $5 \mathrm{~min}$, resolved on $10 \%$ SDS-PAGE, and transferred onto immobilon polyvinylidene difluoride membrane. The membranes were incubated sequentially with an anti-p-GSK-3 $\alpha / \beta\left(\operatorname{Ser}^{21 / 9}\right)$ and anti-AKT antibodies.
Small interfering RNA (siRNA) transfection. The Signalsilence Akt siRNA kit (Cell Signaling) was utilized to disrupt AKT signaling in LNCaP cells. In brief, LNCaP cells were transfected with either non-specific or AKT siRNA (final concentration of $100 \mathrm{nM}$ ) using transfection reagent (Cell Signaling). After 2 days, cells were harvested and subjected to Western blot analysis.

Mice. BALB/c nude mice at 6 weeks of age were purchased from Japan SLC Inc. (Shizuoka, Japan) and were maintained in pathogen-free conditions with irradiated chow.

Treatment protocol. Animals were bilaterally, subcutaneously (s.c.) injected with $2 \times 10^{6}$ DU145, LNCaP, or MDA-MB231 cells/tumor in $0.1 \mathrm{ml}$ Matrigel (Collaborative Biomedical Products, Bedford, MA). These mice were divided randomly into 2 groups of 5 mice each: Group A, received $100 \mu 1$ control diluent (control); Group B, received $100 \mu 1$ water extract of Zanthoxyli Fructus every other day orally for 6 weeks. Tumors were measured every week with vernier calipers. Tumor size was calculated by the formula: a x b x c, where ' $a$ ' is the length and ' $b$ ' is the width and ' $c$ ' is the height in millimeters. At the end of the experiment, animals were sacrificed by $\mathrm{CO}_{2}$ asphyxiation and tumor weights were measured after their careful resection. 


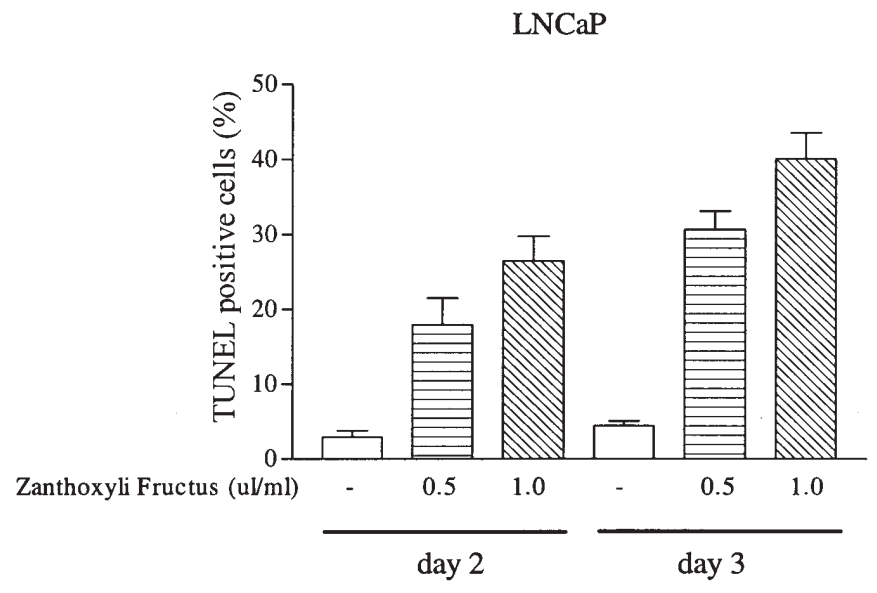

Figure 2. TUNEL assay. LNCaP cells were plated in 96-well plates and cultured either with or without Zanthoxyli Fructus $(0.5$ or $1.0 \mu 1 / \mathrm{ml})$; at 2 or 3 days later, apoptosis was measured by TUNEL assay. Results represent a mean $\pm \mathrm{SD}$ of two experiments performed in triplicate.

Measurement of PSA in mice. Blood was withdrawn from mice several hours before sacrifice. Serum levels of PSA were measured by an immune assay employing the Hybritech Access (Beckman Coulter, Inc., Chaska, MN) according to the manufacturer's protocol.

Histology. Tumors were fixed for $12 \mathrm{~h}$ in $10 \%$ neutral-buffered formaldehyde after sacrifice, tissue blocks were embedded in paraffin, and hematoxylin and eosin-stained sections were examined by light microscopically.
Statistical analysis. Statistical significance of the differences was analyzed by the non-parametric Mann-Whitney U test.

\section{Results}

Effect of Zanthoxyli Fructus on the proliferation of cell lines from prostate, breast, and lung cancers as well as leukemia. Cells were cultured in the presence of various concentrations of Zanthoxyli Fructus (1-4 $\mu \mathrm{l} / \mathrm{ml})$ for 2 days. Dose-response curves were drawn (Fig. 1A-D), and the effective dose that inhibited $50 \%$ of target cells $\left(\mathrm{IC}_{50}\right)$ was determined. All cancer cell lines including those from prostate (LNCaP, DU145, PC3), breast (MCF-7, MDA-MB-231), non-small cell lung (NSCL) (NCI-H520, NCI-H460), acute myeloid leukemia (NB4, HL-60), acute lymphoblastic T-cell leukemia (Jurkat) were effectively inhibited in their proliferation in a dosedependent manner. For example, $\mathrm{IC}_{50}$ of Zanthoxyli Fructus was $0.9,1.8$, and $1.3 \mu \mathrm{l} / \mathrm{ml}$ for LNCaP, T47D, and HL-60 cells, respectively. On the other hand, Zanthoxyli Fructus ( 2 or $4 \mu 1$ / $\mathrm{ml}$ ) did not affect growth of normal myeloid committed stem cells (CFU-GM) from healthy volunteers as measured by the clonogenic soft agar assay (data not shown).

Zanthoxyli Fructus induces apoptosis of LNCaP cells. In further experiments, we studied whether Zanthoxyli Fructus possessed proapoptotic effects against LNCaP cells by employing the TUNEL assay. Zanthoxyli Fructus induced apoptosis in a dose- and time-dependent manner. Exposure of LNCaP cells to either 0.5 or $1.0 \mu \mathrm{l}$ of Zanthoxyli Fructus induced either $18 \pm 3 \%$ or $26 \pm 3 \%$ of these cells, respectively

A

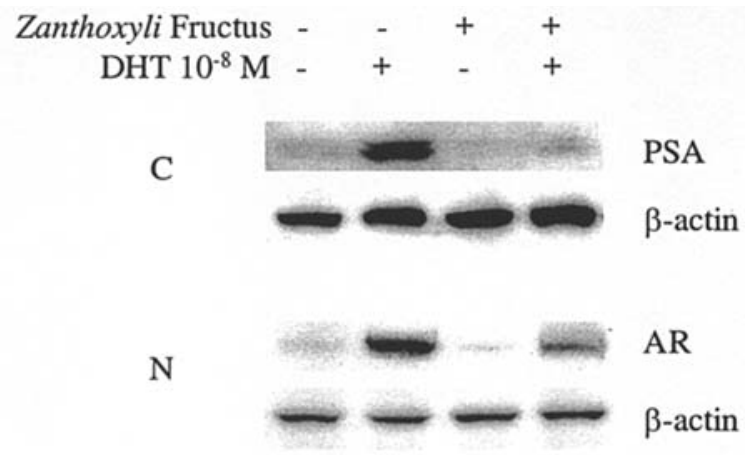

B

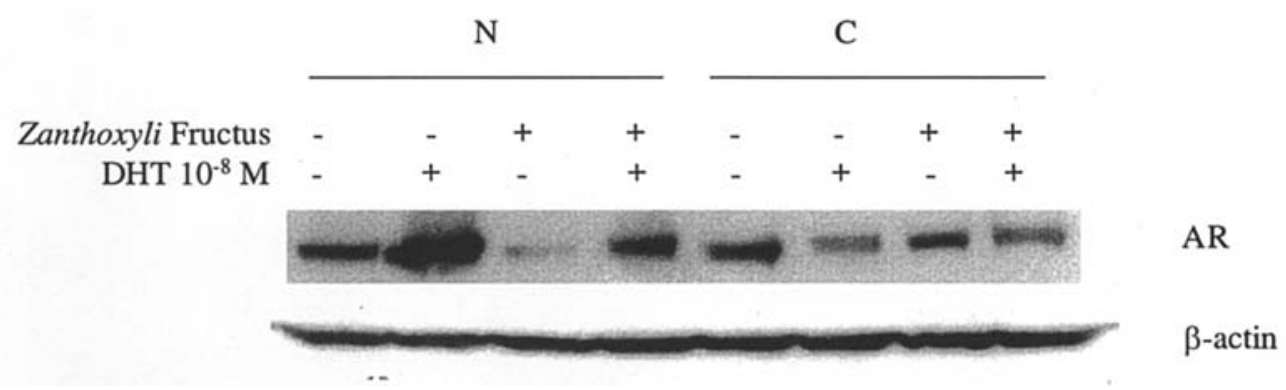

Figure 3. Effect of Zanthoxyli Fructus on expression of PSA and AR. LNCaP cells were placed in culture media containing $10 \%$ charcoal stripped FBS for $24 \mathrm{~h}$ before the addition of either DHT $\left(10^{-8} \mathrm{M}\right)$ alone, or DHT $\left(10^{-8} \mathrm{M}\right)$ in combination with Zanthoxyli Fructus $(0.5 \mu 1 / \mathrm{ml})$. After the addition of reagents, cells were cultured for either $24 \mathrm{~h}(\mathrm{~A})$ or $6 \mathrm{~h}(\mathrm{~B})$, cytoplasmic and nuclear proteins were extracted and subjected to Western blot analysis. The band intensities were measured by densitometry. PSA, prostate specific antigen; AR, androgen receptor; $\mathrm{C}$, cytoplasmic protein; N, nuclear protein. 
A

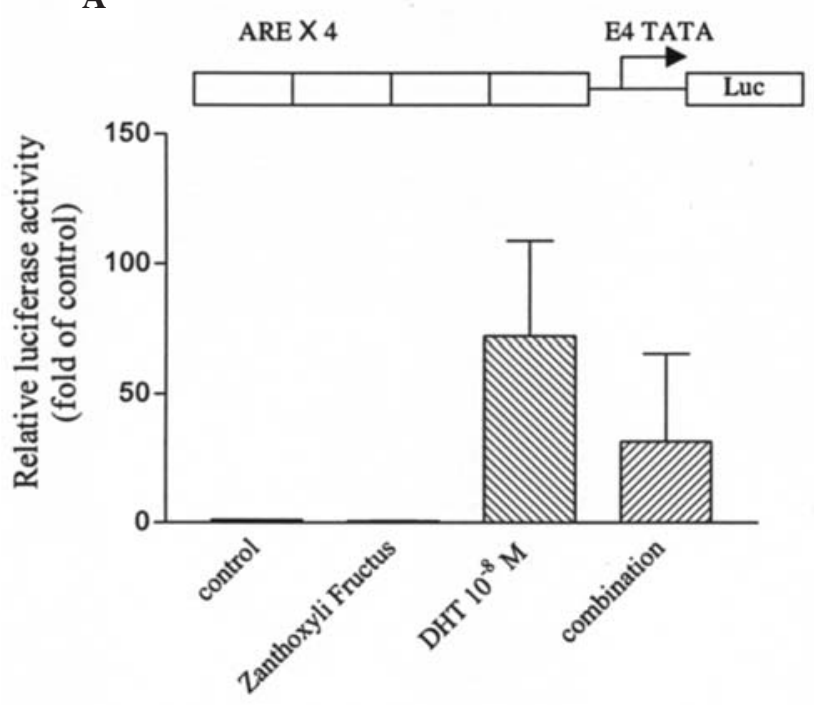

B

PSA enhancer PSA promoter -5322 to $-2925 \quad-564$
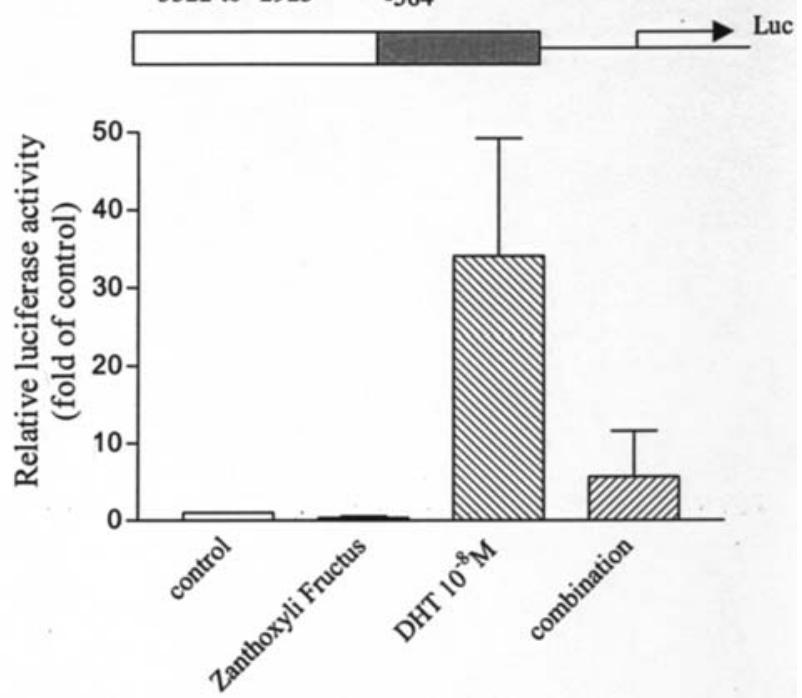

Figure 4. (A) Effect of Zanthoxyli Fructus on ARE activation in LNCaP cells. Shown at the top is the construct (ARE4-E4Lux) containing the 4 concatemerized androgen receptor response elements (ARE) identical to those in the PSA enhancer, which is attached to the luciferase reporter. LNCaP cells were transfected with ARE4-E4Lux $(0.8 \mu \mathrm{g})$. DHT $\left(10^{-8} \mathrm{M}\right)$ was added either with or without Zanthoxyli Fructus $(0.5 \mu 1 / \mathrm{ml})$. (B) Effect of Zanthoxyli Fructus on the transcriptional activity of the PSA promoter/enhancer in LNCaP cells. The reporter construct (PSA P/E-Luc) is shown at the top. LNCaP cells were transfected with PSA P/E-Luc $(0.8 \mu \mathrm{g})$, and DHT $\left(10^{-8} \mathrm{M}\right)$ either with or without Zanthoxyli Fructus $(0.5 \mu 1 / \mathrm{ml})$ was added. pRL-SV40-Luciferase (Renilla luciferase) vector was cotransfected for normalization. Results represent the mean \pm SD of three experiments done in triplicate.

to become apoptotic on the second day of culture, which increased to either $30 \pm 3 \%$ or $41 \pm 2 \%$, respectively, on the third day of culture (Fig. 2). The proapoptotic effects of Zanthoxyli Fructus were also observed in NB4, HL-60, and Jurkat leukemia cells (data not shown).

Effect of Zanthoxyli Fructus on AR signaling. Level of PSA in the control LNCaP cells cultured with charcoal-stripped FBS (10\%, 24 h) was negligible (Fig. 3A). DHT (10-8 M, 24 h) dramatically induced PSA expression in these cells. Exposure of LNCaP cells to Zanthoxyli Fructus $(0.5 \mu 1 / \mathrm{ml}, 24 \mathrm{~h})$ almost completely blocked DHT-induced levels of PSA in these cells. (Fig. 3A). In addition, we explored the effect of Zanthoxyli Fructus on the nuclear level of AR. DHT $\left(10^{-8} \mathrm{M}, 24 \mathrm{~h}\right)$ increased the nuclear levels of AR by $\sim 20$-fold; and the addition of Zanthoxyli Fructus $(0.5 \mu 1 / \mathrm{ml}, 24 \mathrm{~h})$ decreased DHT-induced nuclear levels of AR by $95 \%$ (Fig. 3B). To study whether Zanthoxyli Fructus affects nuclear translocation of AR mediated by DHT, we analyzed levels of AR after a short exposure of the LNCaP cells to DHT (Fig. 3C). DHT (10-8 M,
A
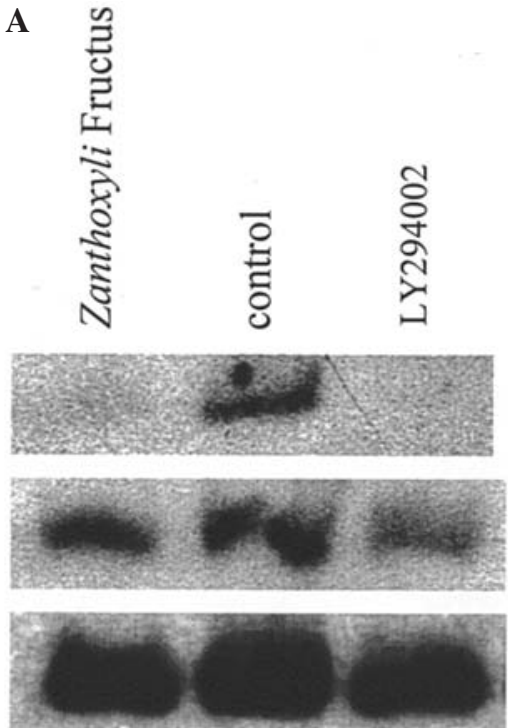

B

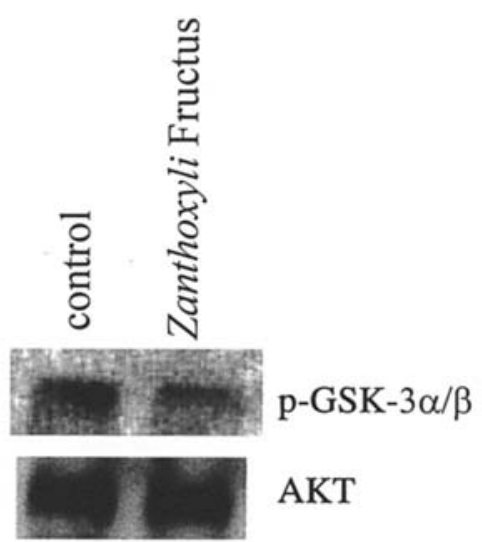

LNCaP
C

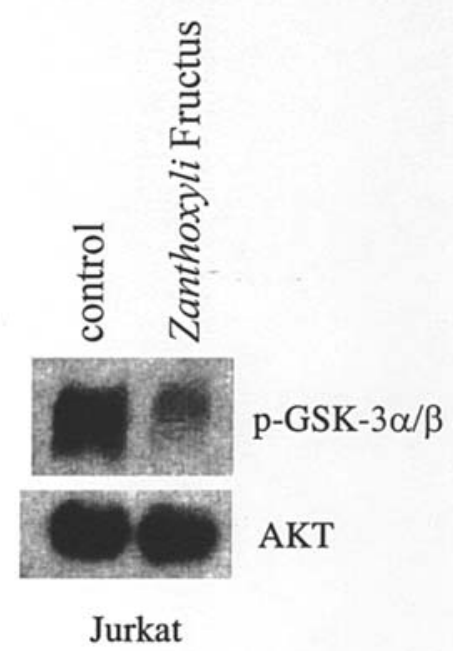

$\beta$-actin

Figure 5. Effect of Zanthoxyli Fructus on AKT activity. (A) Western blot analysis. LNCaP cells were cultured with either Zanthoxyli Fructus (0.5 $\mu 1 / \mathrm{ml})$, LY294002 $\left(2 \times 10^{-5} \mathrm{M}\right)$, or control diluent. After $24 \mathrm{~h}$, cells were harvested and proteins were extracted and subjected to Western blot analysis. The polyvinylidene fluoride membrane was sequentially probed with anti-p-AKT (Ser ${ }^{473}$ ), -AKT, and - $B$-actin antibodies. (B and C) AKT kinase assay. LNCaP (B) or Jurkat (C) cells were cultured either with or without Zanthoxyli Fructus $(0.5 \mu 1 / \mathrm{ml}$ for LNCaP, $2.0 \mu 1 / \mathrm{ml}$ for Jurkat cells). After $24 \mathrm{~h}$, cells were harvested and proteins were extracted and subjected to the AKT kinase assay using recombinant GSK-3 $\alpha / \beta$ as a substrate. The polyvinylidene fluoride membrane was sequentially probed with anti-p-GSK-3 $\alpha / 3\left(\operatorname{Ser}^{21 / 9}\right)$ and -AKT antibodies. 
A

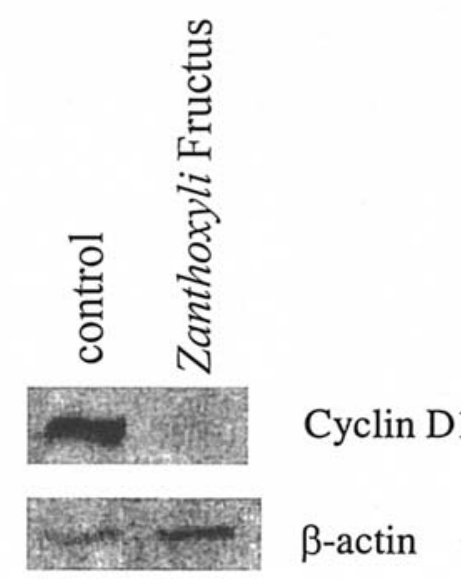

B

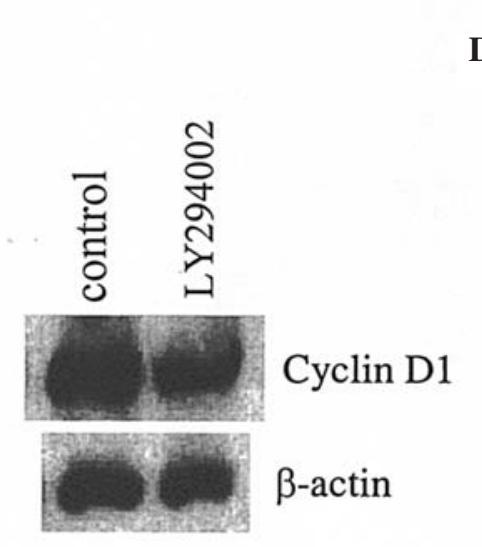

D

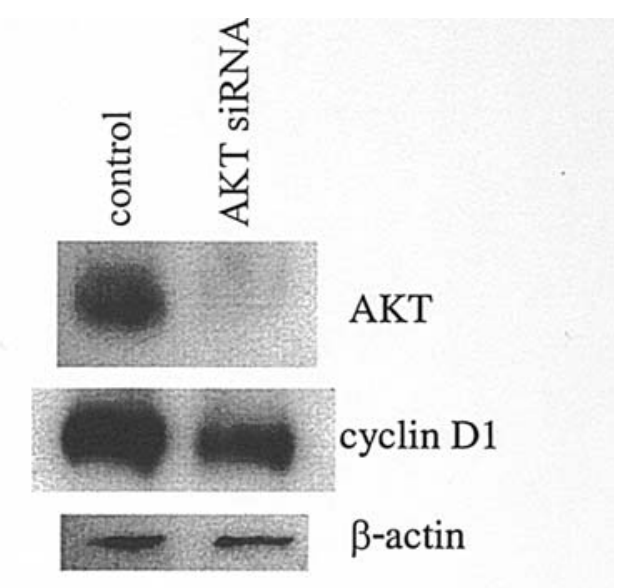

$\mathbf{C}$

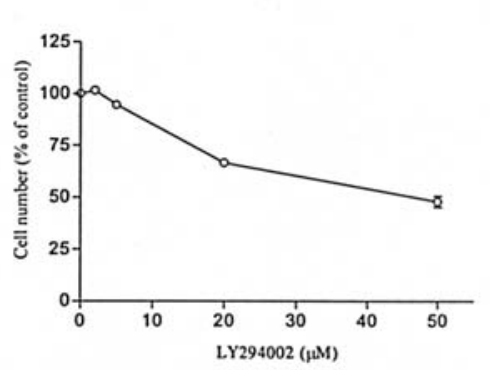

$\mathbf{E}$

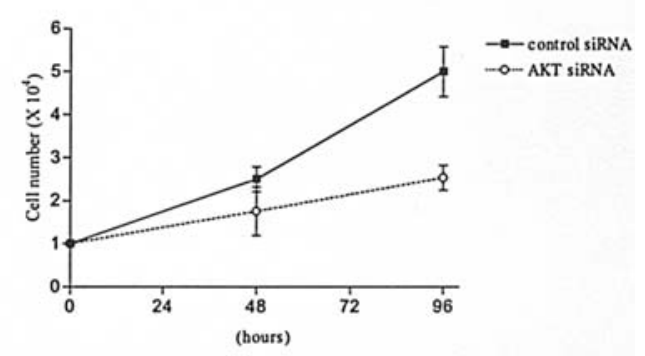

Figure 6. Effect of Zanthoxyli Fructus (A) or LY294002 (B) on cyclin D1 protein. Western blot analysis: LNCaP cells were cultured with either Zanthoxyli Fructus (A) $(0.5 \mu 1 / \mathrm{ml})$ or LY294002 (B) $\left(2 \times 10^{-5} \mathrm{M}\right)$. After $24 \mathrm{~h}$, cells were harvested and proteins were extracted and subjected to Western blot analysis. The polyvinylidene fluoride membrane was sequentially probed with anti-cyclin D1 and - B-actin antibodies. (C) Trypan blue exclusion test: LNCaP cells were plated in 96-well plate and cultured in the presence of LY294002 $\left(2 \times 10^{-6} \mathrm{M}-5 \times 10^{-5} \mathrm{M}\right)$. After 3 days, cell number was counted by trypan blue exclusion test. Results represent the mean \pm SD of triplicate cultures done in duplicate experiments. (D) Transient transfection of AKT siRNA in LNCaP cells: Either control or AKT siRNA was tranfected into LNCaP cells. After $48 \mathrm{~h}$, proteins were extracted and subjected to Western blot analysis. The polyvinylidene fluoride membrane was sequentially probed with anti-AKT, -cyclin D1, and -ß-actin antibodies. (E) Trypan blue exclusion test: Either control or AKT siRNA transfected cells were plated in 96-well plate and cultured for various durations as indicated. Viable cell numbers were evaluated by trypan blue exclusion test. Results represent the mean \pm SD of triplicate cultures done in duplicate experiments.

$6 \mathrm{~h}$ ) increased the nuclear levels of AR by $\sim 5$-fold; Zanthoxyli Fructus $(0.5 \mu \mathrm{l} / \mathrm{ml}, 6 \mathrm{~h})$ decreased DHT-induced nuclear levels of AR by $\sim 70 \%$ (Fig. 3D). At the same time, we extracted cytoplasmic protein and measured levels of AR. Exposure of LNCaP cells to DHT decreased levels of AR in cytoplasm by $50 \%$; however, the addition of Zanthoxyli Fructus did not affect this DHT-induced down-regulation of AR (Fig. 3D), suggesting that Zanthoxyli Fructus did not interfere with DHT-induced nuclear translocation of AR.

Effect of Zanthoxyli Fructus on the promoter of PSA. To explore the effect of Zanthoxyli Fructus on the transcriptional activity of the ligand activated AR, the luciferase reporter construct in which the ARE of the PSA was concatemerized (ARE4-E4Lux) was utilized. LNCaP cells were transfected with ARE4-E4Lux and cultured with DHT $\left(10^{-8} \mathrm{M}\right)$ either with or without Zanthoxyli Fructus $(0.5 \mu 1 / \mathrm{ml})$. The reporter activity increased $\sim 70$-fold when these cells were cultured with DHT $\left(10^{-8} \mathrm{M}, 18 \mathrm{~h}\right)$, as compared to the non-treated control LNCaP cells (Fig. 4C). When the cells were treated with the combination of DHT $\left(10^{-8} \mathrm{M}, 18 \mathrm{~h}\right)$ and Zanthoxyli Fructus $(0.5 \mu \mathrm{l} / \mathrm{ml}, 18 \mathrm{~h})$, luciferase activity was reduced by $55 \%$ compared with DHT alone (Fig. 4A).

We next analyzed the effect of Zanthoxyli Fructus on the ability of DHT to transactivate the PSA promoter/enhancer.
The LNCaP prostate cancer cells were cultured with DHT $\left(10^{-8} \mathrm{M}, 18 \mathrm{~h}\right)$ after they were transfected with the PSA promoter/enhancer-luciferase reporter vector. The reporter activity increased $\sim 30$-fold as compared with non-treated control LNCaP cells (Fig. 4B). When the cells were treated with the combination of DHT $\left(10^{-8} \mathrm{M}, 18 \mathrm{~h}\right)$ and Zanthoxyli Fructus $(0.5 \mu \mathrm{l} / \mathrm{ml}, 18 \mathrm{~h})$, luciferase activity was dramatically reduced by $\sim 85 \%$ compared with DHT alone (Fig. 4B).

Effect of Zanthoxyli Fructus on AKT signaling. LNCaP cells constitutively expressed the phosphorylated form of AKT, and exposure of these cells to Zanthoxyli Fructus $(0.5 \mu 1 / \mathrm{ml}$, $24 \mathrm{~h}$ ) completely blocked phosphorylation of AKT (Fig. 5A). We utilized PI3-K inhibitor LY294002 $\left(2 \times 10^{-5} \mathrm{M}, 24 \mathrm{~h}\right)$ as a positive control, which also down-regulated levels of the phosphorylated form of AKT (Fig. 5A). The effect of Zanthoxyli Fructus on AKT signaling was further studied employing the AKT kinase assay with GSK- $3 \alpha / \beta$ as a substrate. Zanthoxyli Fructus $(0.5 \mu 1 / \mathrm{ml}, 24 \mathrm{~h})$ inhibited AKT kinase activity in LNCaP cells by $\sim 50 \%$ (Fig. 5B). In addition, we studied the effect of Zanthoxyli Fructus on AKT signaling using Jurkat cells in which AKT signaling is activated because of loss of PTEN expression (27). Exposure of these cells to Zanthoxyli Fructus $(2 \mu 1 / \mathrm{ml}, 24 \mathrm{~h})$ inhibited AKT kinase activity by $\sim 80 \%$ (Fig. 5C). 
A

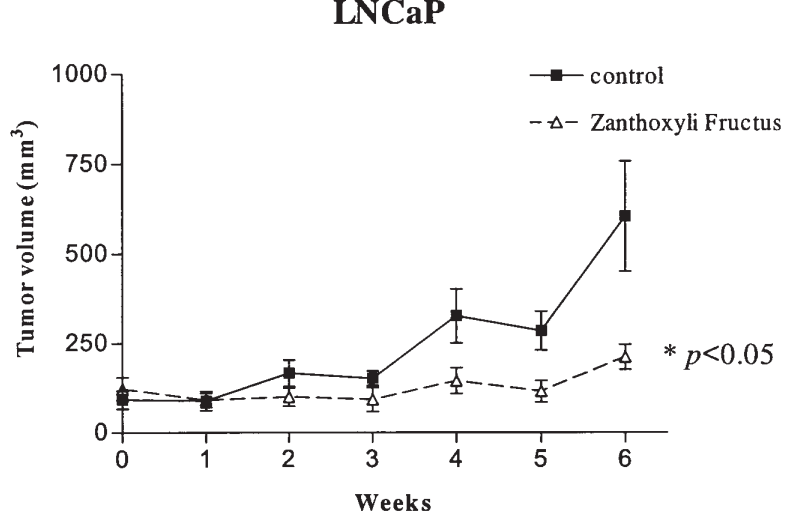

C

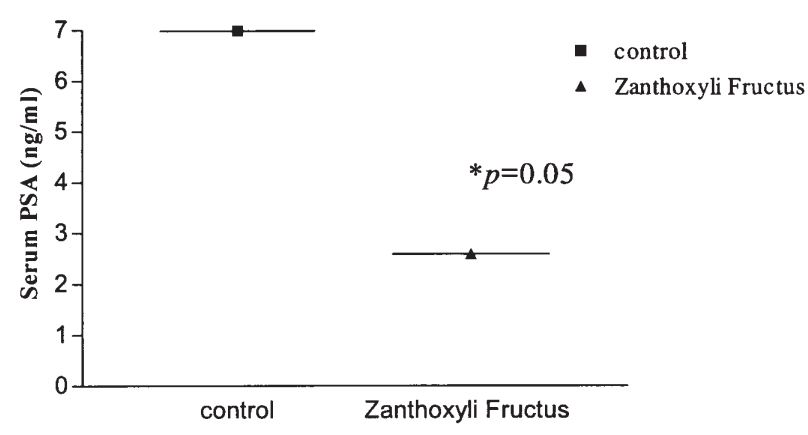

Effect of Zanthoxyli Fructus on expression of cyclin D1. LNCaP cells constitutively expressed cyclin D1 protein; exposure of these cells to Zanthoxyli Fructus $(0.5 \mu 1 / \mathrm{ml}, 24 \mathrm{~h})$ dramatically down-regulated levels of cyclin D1 (Fig. 6A). LY294002 $\left(2 \times 10^{-5} \mathrm{M}, 24 \mathrm{~h}\right)$ also down-regulated levels of cyclin D1 and inhibited growth of $\mathrm{LNCaP}$ cells with an $\mathrm{ED}_{50}$ of $5 \times 10^{-5} \mathrm{M}$ on the third day of culture (Fig. 6B). Furthermore, we transiently transfected AKT siRNA to down-regulate AKT protein. Expression of cyclin D1 was decreased by $\sim 60 \%$ in AKT siRNA transfected cells and their proliferation was slowed compared to non-specific siRNA transfected cells; the doubling time of control siRNA transfected LNCaP cells was $\sim 30 \mathrm{~h}$. On the other hand, the doubling time was prolonged to $98 \mathrm{~h}$ when AKT signaling was blocked by AKT siRNA (Fig. 6E). These results suggested that Zanthoxyli Fructus down-regulated levels of cyclin D1 in LNCaP cells via inhibition of AKT signaling, resulting in growth inhibition.

Effect of Zanthoxyli Fructus on LNCaP cells in vivo. We evaluated the effect of Zanthoxyli Fructus in vivo on LNCaP cells growing in $\mathrm{BALB} / \mathrm{c}$ nude mice. Zanthoxyli Fructus was given by gavage every other day. Tumor volumes were measured weekly. All mice were euthanized after 6 weeks, and tumors were dissected and weighed. Zanthoxyli Fructus significantly suppressed both the growth of LNCaP tumors $(\mathrm{p}<0.05$; Fig. 7A) and their mean weights $(\mathrm{p}<0.05)$ at autopsy (Fig. 7B), as compared with diluant controls.

Blood was withdrawn from mice several hours before they were sacrificed, and levels of PSA were measured. A mean serum levels of PSA in the mice who received Zanthoxyli Fructus was significantly lower than those who received diluent $(2.6 \pm 1.3 \mathrm{ng} / \mathrm{ml}$ vs. $7.0 \pm 2.9 \mathrm{ng} / \mathrm{ml}, \mathrm{p}=0.05)$ (Fig. 7 C). Serum
B

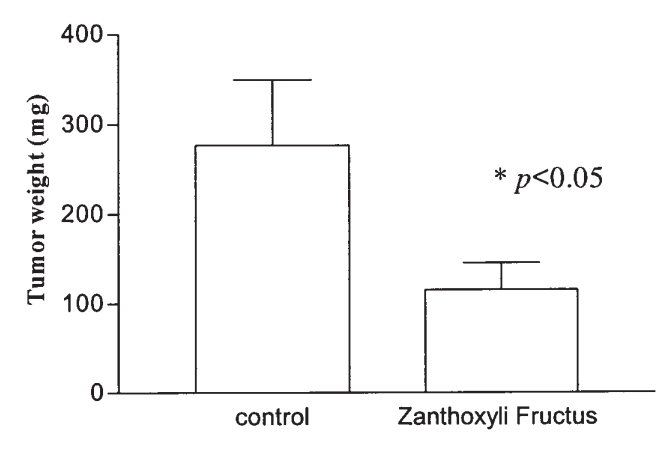

Figure 7. Effect of Zanthoxyli Fructus on growth of LNCaP tumors in nude mice. (A) LNCaP cells were injected bilaterally s.c. into BALB/c nude mice, forming two tumors/mouse. Zanthoxyli Fructus (100 $\mu 1 /$ mouse) was administered orally to mice every other day for 6 weeks. Tumor volumes were measured every week. Each point represents the mean \pm SD of 10 tumors. (B) Tumor weights at autopsy: After 6 weeks of treatment, tumors were removed and weighed. Results represent mean \pm SD of tumor weights. Statistical significance was determined by Mann-Whitney U test. Bars, SD. (C) Serum levels of PSA: After 6 weeks of treatment, blood was withdrawn from each mice and serum levels of PSA were measured.

levels of PSA in normal mice at the same age were $<0.03 \mathrm{ng} / \mathrm{ml}$ (figure not shown).

The tumors and organs of the mice were fixed, stained, and viewed by light microscopy. The tumors from control mice showed typical histological appearance of infiltrating, poorly differentiated adenocarcinomas of the prostate (Fig. 8A). Tumors from mice receiving Zanthoxyli Fructus had marked fibrosis (Fig. 8B). Some tumor cells treated with Zanthoxyli Fructus showed pyknotic nuclei and cytoplasmic shrinkage with eosinophilia, indicating that they were undergoing apoptosis (Fig. 8C). Organs from mice treated with Zanthoxyli Fructus did not show any changes compared to controls, including their livers, kidneys, spleens, lungs, and hearts. During the study, all the mice were weighed each week; the mean weights of the experimental groups were statistically the same as those of the control mice (data not shown).

Effect of Zanthoxyli Fructus on DU145 androgen-independent prostate and MDA-MB123 breast cancer cells in vivo. We also examined anti-tumor effects of Zanthoxyli Fructus in vivo using a more aggressive form of prostate cancer (DU145) as well as aggressive breast cancer MDA-MB123 cells. As shown in Fig. 9, Zanthoxyli Fructus significantly $(\mathrm{p}<0.05)$ slowed their growth (Fig. 9A and $\mathrm{C}$ ) and significantly $(\mathrm{p}<0.03)$ reduced their tumor weights at autopsy (Fig. 9 B and D).

\section{Discussion}

Zanthoxyli Fructus possessed anti-tumor activity against a wide variety of cancer types. Among them, androgen-dependent human prostate cancer $\mathrm{LNCaP}$ cells were most sensitive to growth inhibition by Zanthoxyli Fructus. The proliferation of 
A

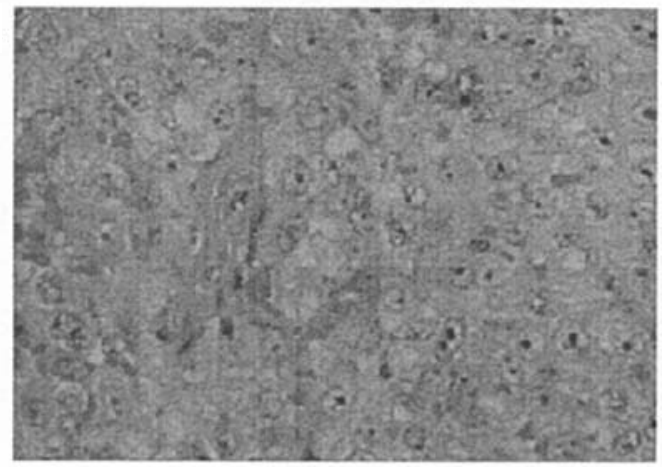

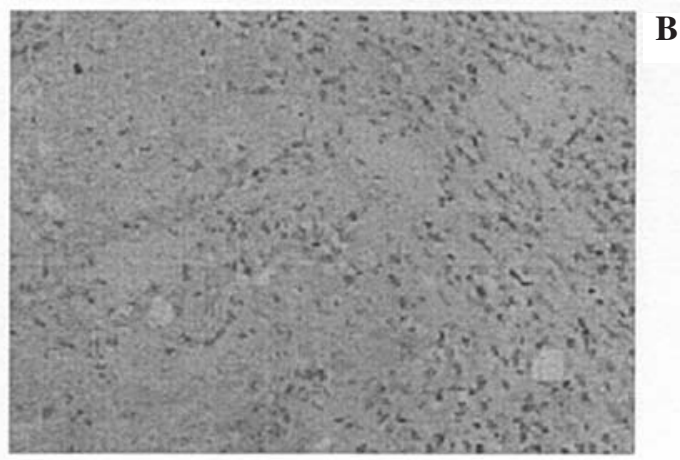

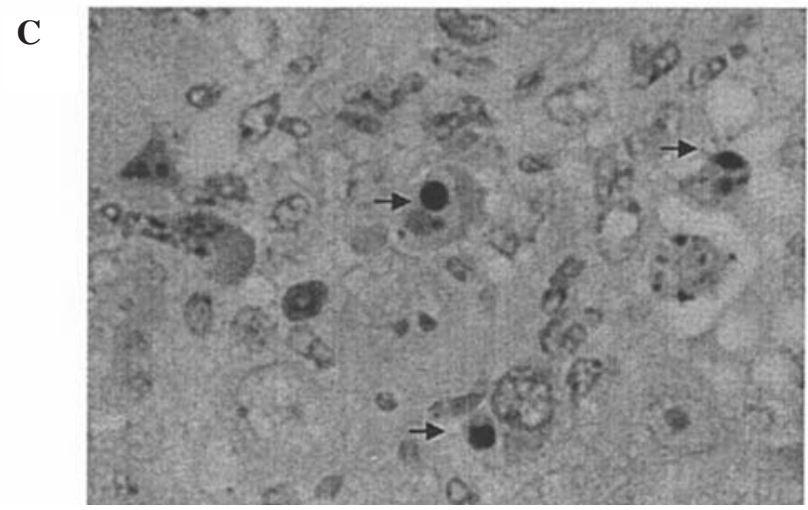

Figure 8. Histology of LNCaP human prostate tumors from mice treated with Zanthoxyli Fructus in vivo. After 6 weeks of growth in nude mice either with or without treatment with Zanthoxyli Fructus, LNCaP tumors were removed, fixed in formalin, and stained with H\&E. (A) Control tumors from mice that received diluent displayed poorly differentiated adenocarcinoma (x200). (B) Tumors from mice treated with Zanthoxyli Fructus (100 $\mu 1 /$ mouse) every other day for 6 weeks showed marked fibrosis (x200); and (C) a prominent population of these cells had pyknotic nuclei (arrows) and cytoplasmic eosinophilia, indicating apoptosis $(\mathrm{x} 400)$.

LNCaP cells is under the control of AR signaling. In addition, AKT signaling is activated because of loss of PTEN expression, which contributes to their proliferation (16). Importantly, Zanthoxyli Fructus blocked both of these signal pathways. PTEN is also inactivated in PC-3 cells because of homozygous deletion, resulting in activation of AKT signaling (14). However, PC-3 cells are androgen-independent and their proliferation was not under the control of AR signaling. This could explain why PC-3 cells were less sensitive to growth inhibition by Zanthoxyli Fructus compared to LNCaP cells. DU145 prostate cancer cells are also androgen-independent. DU145 cells express PTEN protein and AKT signaling is inactivated and does not contribute to their proliferation (28). On the other hand, other survival factors such as nuclear factor- $\mathrm{\kappa B}(\mathrm{NF}-\mathrm{\kappa B})$ and signal transducer and activator of transcription 3 (STAT3) were activated in DU145 cells and regulated their proliferation (29). Zanthoxyli Fructus was not able to inhibit these cell survival factors (data not shown). At the present time, the molecular mechanism(s) by which Zanthoxyli Fructus inhibited the growth of DU145 cells remains unknown.

The activated AKT signaling is implicated in drug resistance of cancer cells. For example, forced expression of AKT resulted in enhanced drug resistance of NCI-H460 cells towards a panel of chemotherapeutic agents (30). Inhibition of the AKT signaling pathway sensitized cancer cells to the anticancer agents; for example, the PI3-K inhibitor LY294002 reduced resistance of HL-60 AR cells (PI3K/AKT signaling was constitutively activated) to retinoid, etoposide, and cytarabine (31). Moreovere, disruption of AKT signaling by the mTOR inhibitor rapamycin reversed chemoresistance in murine lymphoma cells in vivo (32). Zanthoxyli Fructus might sensitize cancer cells to chemotherapeutic agents via inhibition of AKT signaling.

Zanthoxyli Fructus decreased levels of cyclin D1 protein (Fig. 6A). We hypothesize that down-regulation of cyclin D1 by Zanthoxyli Fructus was mediated by inhibition of AKT kinase; our data suggested that inactivation of AKT stimulated GSK-3 kinase which probably phosphorylated cyclin D1 on Thr286 and shorten the half-life of cyclin D1 protein in LNCaP cells. Furthermore, when we disrupted AKT signaling in LNCaP cells by either the PI3-K inhibitor LY294002 or AKT siRNA, levels of cyclin D1 protein decreased associated with slowing cell growth (Fig. 6). These observations further augmented the hypothesis that Zanthoxyli Fructus down-regulated cyclin D1 via inhibition of AKT signaling.

AKT siRNA completely down-regulated levels of AKT, resulted in $40 \%$ reduction of cyclin D1 protein (Fig. 6D). Zanthoxyli Fructus $(0.5 \mu 1 / \mathrm{ml}, 24 \mathrm{~h})$ almost completely blocked expression of cyclin D1 protein, while inhibition of AKT kinase activity by Zanthoxyli Fructus $(0.5 \mu 1 / \mathrm{ml}, 24 \mathrm{~h})$ was $\sim 50 \%$ (Figs. 5B and 6A). AKT may not be the only target of Zanthoxyli Fructus. For example, activation of 
A

DU145

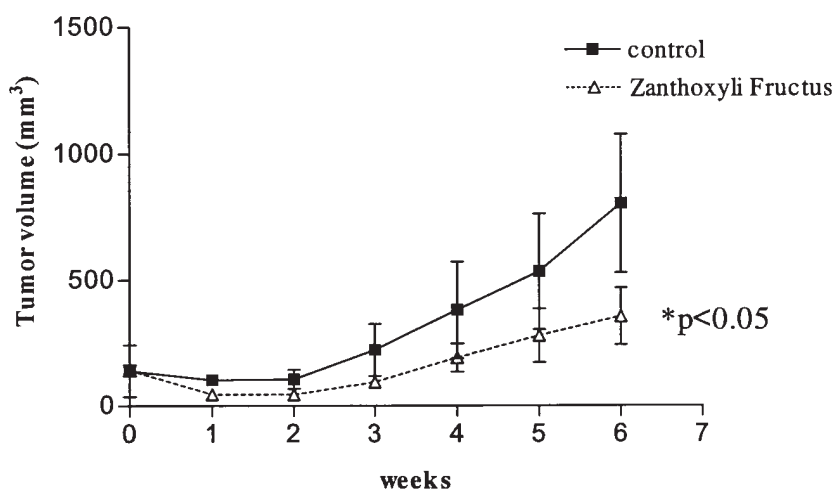

$\mathrm{C}$

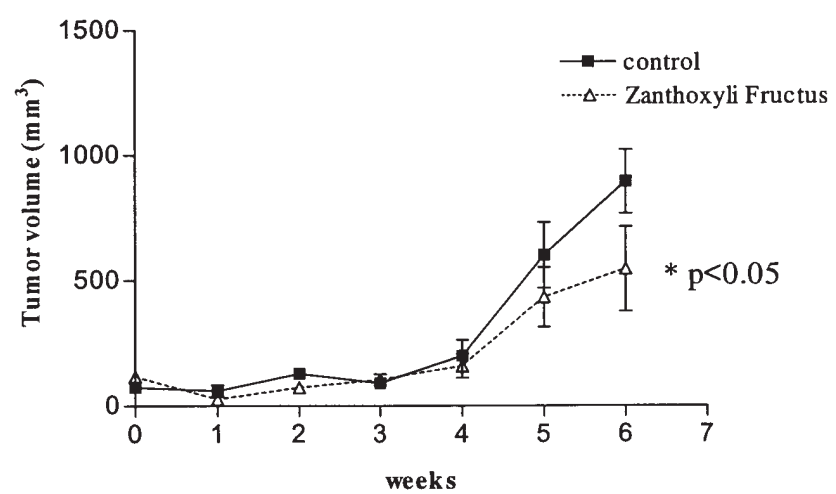

B

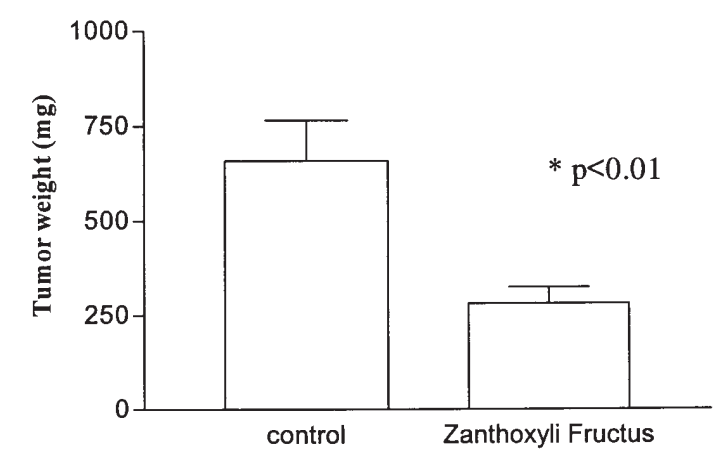

D

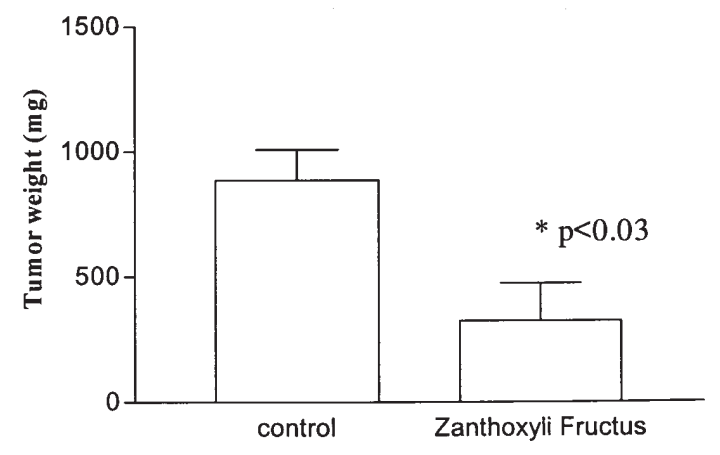

Figure 9. Effect of Zanthoxyli Fructus on growth of tumors formed by DU145 prostate cancer cells (A and B) and MDA-MB123 (C and D) breast cancer cells in nude mice. DU145 (A) or MDA-MB231 (C) cells were injected bilaterally s.c. into BALB/c nude mice, forming two tumors/mouse. Zanthoxyli Fructus (100 $\mu \mathrm{l} /$ mouse) was administered to mice every other day for 6 weeks. Tumor volumes were measured every week. Each point represents the mean \pm SD of 10 tumors. (B and D), Tumor weights at autopsy. After 6 weeks of treatment, DU145 (B) or MDA-MB123 (D) tumors were removed and weighed. Results represent mean $\pm \mathrm{SD}$ of tumor weights. Statistical significance was determined by Mann-Whitney U test.

p21-activated kinase 1 (PAK1) and integrin-linked kinase (ILK) locate downstream of PI3-K and stimulates expression of cyclin D1 $(33,34)$. Zanthoxyli Fructus could affect these kinases.

We always monitor purity of herb by $3 \mathrm{D}$ chromatography (25). A different batch of Zanthoxyli Fructus (lot no. 2041094010) showed an identical fingerprint pattern and similarly inhibited growth of LNCaP cells (data not shown).

Taken together, Zanthoxyli Fructus was active against a wide variety of cancer cell types. It showed the strongest anti-tumor activity against the LNCaP androgen-dependent prostate cancer cells in conjunction with blockade of AKT and AR signaling. Zanthoxyli Fructus might be useful as an adjunctive therapeutic agent for individuals with cancer. Further study will purify the active component(s) of Zanthoxyli Fructus.

\section{Acknowledgements}

This study was supported in part by a Grant-in-Aid from the Ministry of Education, Culture Sports, Science, and Technology of Japan. H.P.K. is supported by NIH grants, Parker Hughes Fund and the Inger Fund.

\section{References}

1. Hayakawa T, Kase Y, Saito K, Hashimoto K, Ishige A, Komatsu Y and Sasaki H: Pharmacological studies of the effect of Dai-kenchu-to on spontaneous contraction of isolated rabbit jejunum. J Smooth Muscle Res 35: 55-62, 1999.

2. Quigley CA, DeBellis A, Marschke KB, El-Awady MK, Wilson EM and French FS: Androgen receptor defects: historical, clinical, and molecular perspectives. Endocr Rev 16: 271-321, 1995.

3. Gelmann EP: Molecular biology of the androgen receptor. J Clin Oncol 20: 3001-3015, 2002.

4. Chen CD, Welsbie DS, Tran C, et al: Molecular determinants of resistance to antiandrogen therapy. Nat Med 10: 33-39, 2004.

5. Polascik TJ, Oesterling JE and Partin AW: Prostate specific antigen: a decade of discovery - what we have learned and where we are going. J Urol 162: 293-306, 1999.

6. Pang S, Dannull J, Kaboo R, et al: Identification of a positive regulatory element responsible for tissue-specific expression of prostate-specific antigen. Cancer Res 57: 495-499, 1997.

7. Huang W, Shostak Y, Tarr P, Sawyers C and Carey M: Cooperative assembly of androgen receptor into a nucleoprotein complex that regulates the prostate-specific antigen enhancer. J Biol Chem 274: 25756-25768, 1999.

8. Schuur ER, Henderson GA, Kmetec LA, Lamparski HG, Miller JD and Henderson DR: Prostate-specific antigen expression is regulated by an upstream enhancer. $\mathrm{J}$ Biol Chem 271: 7043-7051, 1996.

9. Franke TF, Kaplan DR and Cantley LC: PI3K: downstream AKTion blocks apoptosis. Cell 88: 435-437, 1997. 
10. Cardone MH, Roy N, Stennicke HR, et al: Regulation of cell death protease caspase- 9 by phosphorylation. Science 282 : 1318-1321, 1998.

11. Brunet A, Bonni A, Zigmond MJ, et al: Akt promotes cell survival by phosphorylating and inhibiting a Forkhead transcription factor. Cell 96: 857-868, 1999.

12. Wang Q, Wang X, Hernandez A, Hellmich MR, Gatalica Z and Evers BM: Regulation of TRAIL expression by the phosphatidylinositol 3-kinase/Akt/GSK-3 pathway in human colon cancer cells. J Biol Chem 277: 36602-36610, 2002.

13. Davies MA, Kim SJ, Parikh NU, Dong Z, Bucana CD and Gallick GE: Adenoviral-mediated expression of MMAC/PTEN inhibits proliferation and metastasis of human prostate cancer cells. Clin Cancer Res 8: 1904-1914, 2002.

14. Steck PA, Pershouse MA, Jasser SA, et al: Identification of a candidate tumor suppressor gene, $M M A C 1$, at chromosome $10 \mathrm{q} 23.3$ that is mutated in multiple advanced cancers. Nat Genet 15: 356-362, 1997.

15. Li J, Yen C, Liaw D, et al: PTEN, a putative protein tyrosine phosphatase gene mutated in human brain, breast, and prostate cancer. Science 275: 1943-1947, 1997.

16. Wu X, Senechal K, Neshat MS, Whang YE and Sawyers CL: The PTEN/MMAC1 tumor suppressor phosphatase functions as a negative regulator of the phosphoinositide 3-kinase/Akt pathway. Proc Natl Acad Sci USA 95: 15587-15591, 1998.

17. Matsushime H, Roussel MF, Ashmun RA and Sherr CJ: Colonystimulating factor 1 regulates novel cyclins during the G1 phase of the cell cycle. Cell 65: 701-713, 1991.

18. Watts CK, Sweeney KJ, Warlters A, Musgrove EA and Sutherland RL: Antiestrogen regulation of cell cycle progression and cyclin D1 gene expression in MCF-7 human breast cancer cells. Breast Cancer Res Treat 31: 95-105, 1994.

19. Weinberg RA: The retinoblastoma protein and cell cycle control. Cell 81: 323-330, 1995.

20. Filmus J, Robles AI, Shi W, Wong MJ, Colombo LL and Conti CJ: Induction of cyclin D1 overexpression by activated ras. Oncogene 9: 3627-3633, 1994.

21. Buckley MF, Sweeney KJ, Hamilton JA, et al: Expression and amplification of cyclin genes in human breast cancer. Oncogene 8: 2127-2133, 1993.

22. Bartkova J, Lukas J, Strauss M and Bartek J: Cyclin D1 oncoprotein aberrantly accumulates in malignancies of diverse histogenesis. Oncogene 10: 775-778, 1995.

23. Perry JE, Grossmann ME and Tindall DJ: Epidermal growth factor induces cyclin D1 in a human prostate cancer cell line. Prostate 35: 117-124, 1998.
24. Diehl JA, Cheng M, Roussel MF and Sherr CJ: Glycogen synthase kinase-3beta regulates cyclin D1 proteolysis and subcellular localization. Genes Dev 12: 3499-3511, 1998.

25. Ohtake N, Nakai Y, Yamamoto M, Sakakibara I, Takeda S, Amagaya S and Aburada M: Separation and isolation methods for analysis of the active principles of Sho-saiko-to (SST) oriental medicine. J Chromatogr B Analyt Technol Biomed Life Sci 812: 135-148, 2004.

26. Ikezoe T, Yang Y, Saito T, Koeffler HP and Taguchi $\mathrm{H}$ : Proteasome inhibitor PS-341 down-regulates level of PSA and induces growth arrest and apoptosis of androgen-dependent human prostate cancer LNCaP cells. Cancer Sci 95: 271-275, 2004.

27. Uddin S, Hussain A, Al-Hussein K, Platanias LC and Bhatia KG: Inhibition of phosphatidylinositol 3-kinase induces preferentially killing of PTEN-null T leukemias through AKT pathway. Biochem Biophys Res Commun 320: 932-938, 2004.

28. Bastola DR, Pahwa GS, Lin MF and Cheng PW: Downregulation of PTEN/MMAC/TEP1 expression in human prostate cancer cell line DU145 by growth stimuli. Mol Cell Biochem 236: 75-81, 2002.

29. Barton BE, Karras JG, Murphy TF, Barton A and Huang HF: Signal transducer and activator of transcription 3 (STAT3) activation in prostate cancer: direct STAT3 inhibition induces apoptosis in prostate cancer lines. Mol Cancer Ther 3: 11-20, 2004

30. Hovelmann S, Beckers TL and Schmidt M: Molecular alterations in apoptotic pathways after PKB/Akt-mediated chemoresistance in NCI H460 cells. Br J Cancer 90: 2370-2377, 2004.

31. Martelli AM, Tazzari PL, Tabellini G, et al: A new selective AKT pharmacological inhibitor reduces resistance to chemotherapeutic drugs, TRAIL, all-trans-retinoic acid, and ionizing radiation of human leukemia cells. Leukemia 17: 1794-1805, 2003.

32. Wendel HG, De Stanchina E, Fridman JS, et al: Survival signalling by Akt and eIF4E in oncogenesis and cancer therapy. Nature 428: 332-337, 2004

33. Dadke D, Fryer BH, Golemis EA and Field J: Activation of p21activated kinase 1-nuclear factor kappaB signaling by Kaposi's sarcoma-associated herpes virus $\mathrm{G}$ protein-coupled receptor during cellular transformation. Cancer Res 63: 8837-8847, 2003.

34. Radeva G, Petrocelli T, Behrend E, Leung-Hagesteijn C, Filmus J, Slingerland J and Dedhar S: Overexpression of the integrin-linked kinase promotes anchorage-independent cell cycle progression. J Biol Chem 272: 13937-13944, 1997. 